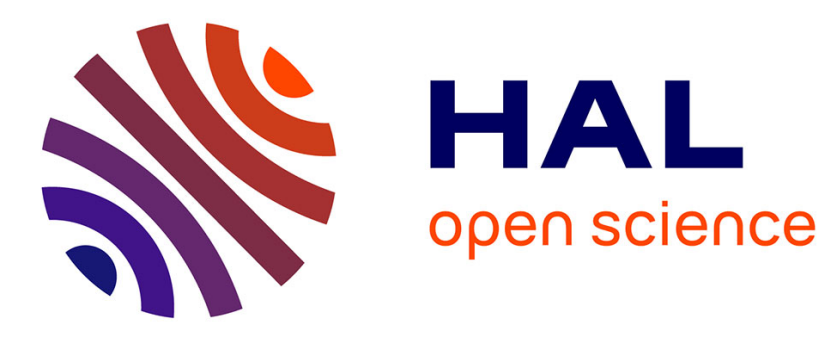

\title{
Current use of and future needs for soil invertebrate functional traits in community ecology
}

Benjamin Pey, Johanne Nahmani, Apolline Auclerc, Yvan Capowiez, Daniel Cluzeau, Jérôme Cortet, Thibaud Decaens, Louis Deharveng, Florence Dubs, Sophie Joimel, et al.

\section{To cite this version:}

Benjamin Pey, Johanne Nahmani, Apolline Auclerc, Yvan Capowiez, Daniel Cluzeau, et al.. Current use of and future needs for soil invertebrate functional traits in community ecology. Basic and Applied Ecology, 2014, 15 (3), pp.194-206. 10.1016/j.baae.2014.03.007 . hal-01005001

\section{HAL Id: hal-01005001 https://hal.science/hal-01005001}

Submitted on 11 Jun 2014

HAL is a multi-disciplinary open access archive for the deposit and dissemination of scientific research documents, whether they are published or not. The documents may come from teaching and research institutions in France or abroad, or from public or private research centers.
L'archive ouverte pluridisciplinaire HAL, est destinée au dépôt et à la diffusion de documents scientifiques de niveau recherche, publiés ou non, émanant des établissements d'enseignement et de recherche français ou étrangers, des laboratoires publics ou privés. 


\section{Current use of and future needs for soil invertebrate functional}

\section{traits in community ecology}

Benjamin PEY ${ }^{\mathrm{a}, \mathrm{b}}$, Johanne NAHMANI ${ }^{\mathrm{c}}$, Apolline AUCLERC ${ }^{\mathrm{d}}$, Yvan CAPOWIEZ ${ }^{\mathrm{e}}$, Daniel CLUZEAU ${ }^{\mathrm{f}}$, Jérôme CORTET ${ }^{\mathrm{g}}$, Thibaud DECAËNS ${ }^{\mathrm{h}}$, Louis DEHARVENG ${ }^{\mathrm{i}}$, Florence DUBS $^{\mathrm{j}}$, Sophie JOIMEL ${ }^{\mathrm{k}}$, Charlène BRIARD ${ }^{\mathrm{f}}$, Fabien GRUMIAUX ${ }^{\mathrm{l}}$, Marie-Angélique LAPORTE $^{\mathrm{m}}$, Alain PASQUET ${ }^{\mathrm{n}}$, Céline PELOSI ${ }^{\mathrm{a}}$, Céline PERNIN ${ }^{\mathrm{l}}$, Jean-François PONGE ${ }^{\mathrm{o}}$, Sandrine SALMON ${ }^{\mathrm{o}}$, Lucia SANTORUFO ${ }^{\mathrm{k}, \mathrm{p}}$, Mickaël HEDDE ${ }^{*}$,a ${ }^{a}$ INRA, UR251 PESSAC, RD 10, 78026 Versailles Cedex, France

${ }^{b}$ CESAB/FRB, Domaine du Petit Arbois, Avenue Louis Philibert, 13545 Aix-en-Provence, France

${ }^{c}$ Centre d'Ecologie Fonctionnelle et Evolutive (CEFE), CNRS, Université de Montpellier II, Montpellier, France

${ }^{d}$ University of Michigan, Department of Ecology and Evolutionary Biology, Ann Arbor, Michigan, USA

${ }^{e}$ INRA, UR1115 « Plantes et Systèmes Horticoles », Domaine Saint-Paul, 84914 Avignon Cedex 09, France

fUniversité de Rennes 1, UMR CNRS 6553 «EcoBio », Station Biologique, 35380 Paimpont, France

${ }^{g}$ Université Paul Valéry Montpellier III, Centre d'Ecologie Fonctionnelle et évolutive, Laboratoire de Zoogéographie, UMR 5175 CEFE, route de Mende, 34199 Montpellier cedex

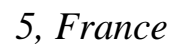

${ }^{h}$ UFR Sciences et Techniques, EA 1293 «ECODIV», Université de Rouen, 76821 Mont Saint Aignan Cedex, France ${ }^{i}$ CNRS, UMR 7205, Muséum National d'Histoire Naturelle, CP50, 45 rue Buffon, 75005 Paris, France 
${ }^{k}$ INRA/INPL, UMR 1120 « Laboratoire Sols et Environnement », Nancy-Université, 2 avenue de la Forêt de Haye, BP 172, 54505 Vandœuvre-lès-Nancy Cedex, France

lUniversité de Lille 1, EA 4515 «Laboratoire Génie Civil \& géo Environnement », Lille Nord de France, Ecologie Numérique et Ecotoxicologie - Bat SN3, 59655 Villeneuve d'Ascq Cedex,

50 * Corresponding author. Tel.: +33 (0)6 221354 78; fax: +33 (0)3 83595791.

51 E-mail address: mickael.hedde@versailles.inra.fr.

\section{France}

${ }^{m}$ IRD, UMR 228 ESPACE-DEV, 500 rue Jean-François Breton, 34093 Montpellier Cedex, France

${ }^{n}$ UR AFPA, Faculté des Sciences et Technologies, Université de Lorraine, Boulevard des Aiguillettes, BP 239, 54506 Vandœuvre-lès-Nancy Cedex, France ${ }^{\circ}$ CNRS, UMR 7179, Muséum National d'Histoire Naturelle, 4 Avenue du Petit-Château, 91800 Brunoy, France

${ }^{p}$ Department of Structural and Functional Biology, University of Naples Federico II, Complesso Universitario di Monte Sant’Angelo, Via Cinthia, 80126 Naples, Italy 0

1

2

3

4

45

\section{6}

7

8

\section{9}




\section{Abstract}

53 Soil invertebrates are assumed to play a major role in ecosystem dynamics, since they are

54 involved in soil functioning. Functional traits represent one of the main opportunities to bring

55 new insights into the understanding of soil invertebrate responses to environmental changes.

56 They are properties of individuals which govern their responses to their environment. As no

57 clear conceptual overview of soil invertebrate trait definitions is available, we first stress that

58 previously-described concepts of trait are applicable to soil invertebrate ecology after minor

59 modification, as for instance the inclusion of behavioural traits. A decade of literature on the

60 use of traits for assessing the effects of the environment on soil invertebrates is then reviewed.

61 Trait-based approaches may improve the understanding of soil invertebrate responses to

62 environmental changes as they help to establish relationships between environmental changes

63 and soil invertebrates. Very many of the articles are dedicated to the effect of one kind of

64 stress at limited spatial scales. Underlying mechanisms of assembly rules were sometimes

65 assessed. The patterns described seemed to be similar to those described for other research

66 fields (e.g. plants). The literature suggests that trait-based approaches have not been reliable

67 over eco-regions. Nevertheless, current work gives some insights into which traits might be

68 more useful than others to respond to a particular kind of environmental change. This review

69 also highlights methodological advantages and drawbacks. First, trait-based approaches

70 provide complementary information to taxonomic ones. However the literature does not allow

71 us to differentiate between trait-based approaches and the use of a priori functional groups. It

72 also reveals methodological shortcomings. For instance, the ambiguity of the trait names can

73 impede data gathering, or the use of traits at a species level, which can hinder scientific

74 interpretation as intra-specific variability is not taken into account and may lead to some

75 biases. To overcome these shortcomings, the last part aims at proposing some solutions and 
76 prospects. It concerns notably the development of a trait database and a thesaurus to improve

77 data management.

78

79 Keywords: behaviour, community ecology, constraint, database management system,

80 disturbance, ecological preference, life-history trait, soil fauna, thesaurus

81 
Zusammenfassung

Man nimmt an, dass wirbellose Bodentiere eine wichtige Rolle bei der

Ökosystemdynamik spielen, da sie am Funktionieren der Böden beteiligt sind.

Funktionelle Merkmale bilden eine der wichtigsten Möglichkeiten für ein neues Verständnis der Reaktion von Bodenwirbellosen auf Umweltänderungen. Es handelt sich um Eigenschaften von Individuen, die deren Reaktion auf die Umwelt bestimmen. Da es keinen klaren konzeptionellen Überblick über die Merkmalsdefinitionen für Bodenwirbellose gibt, betonen wir zunächst, dass existierende Konzepte nach geringen Modifikationen auf die Ökologie von Bodenwirbellosen anwendbar sind, wie z.B. das Einbeziehen von Verhaltensmerkmalen. Anschließend betrachten wir ein Jahrzehnt der Literatur zum Gebrauch von Merkmalen bei der Abschätzung der Effekte der Umwelt auf Bodenwirbellose. Merkmalsbasierte Ansätze können unser Verständnis der Reaktionen von Bodenwirbellosen auf Umweltänderungen verbessern, da sie helfen, Beziehungen zwischen Umweltänderungen und Bodenwirbellosen zu etablieren. Sehr viele der Artikel widmen sich dem Effekt eines Stressfaktors auf begrenzten räumlichen Skalen. Die zugrundeliegenden Mechanismen von Vergemeinschaftungsregeln wurden manchmal bestimmt. Die beschriebenen Muster scheinen denen von anderen Forschungsgebieten (z.B. Pflanzen) ähnlich zu sein. Die Literatur legt nahe, dass merkmalsbasierte Ansätze über Ökoregionen hinweg nicht zuverlässig sind. Nichtsdestotrotz lassen aktuelle Arbeiten erkennen, welche Merkmale nützlicher als andere sein könnten, um auf spezielle Umweltveränderungen zu reagieren. Diese Arbeit stellt auch methodische Vor- und Nachteile heraus. Zuerst liefern merkmalsbasierte Ansätze Informationen, die taxonomische ergänzen. Indessen erlaubt uns die Literatur nicht, zwischen merkmalsbasierten Ansätzen und dem Gebrauch von apriori definierten funktionellen Gruppen zu unterscheiden. Sie zeigt auch methodische Unzulänglichkeiten. So kann z.B. die Mehrdeutigkeit von Merkmalsbezeichungen das Sammeln von Daten behindern, oder der Gebrauch 
110 von Merkmalen auf der Artebene, der die wissenschaftliche Interpretation

111 erschweren kann, da die intraspezifische Variabilität nicht berücksichtigt wird

112 und zu gewissen Verzerrungen führen kann. Um diese Unzulänglichkeiten zu

113 überwinden, hat der letzte Teil zum Ziel, einige Lösungen und Ausblicke

114 vorzuschlagen. Dies betrifft namentlich die Entwicklung einer

115 Merkmalsdatenbank und eines Thesaurus' um die Datenverwaltung zu

116 verbessern.

117

118

119

120 
120

121

122

123

124

125

126

127

128

130

131

132

133

134

135

136

137

138

139

140

141

142

143

144

\section{Introduction}

The current biodiversity estimation of soil fauna assumes that soil is the third biotic frontier after tropical forest canopies and ocean abysses (Swift, Heal \& Anderson 1979; André, Noti \& Lebrun 1994; Giller 1996; Wolters 2001). The soil fauna encompasses both the obligate and facultative inhabitants of soil and soil annexes (Wolters 2001). Soil annexes are simple structures which diversify the soil surface (e.g. tree stumps)(Gobat, Aragno \& Matthey 1998). The soil includes a variety of animals from almost all major taxa that compose the terrestrial animal communities and may represent as one quarter of all currently described biodiversity (Decaëns, Jimenez, Gioia, Measey \& Lavelle 2006). Soil invertebrates are assumed to play a major role in ecosystem dynamics, since they are involved in soil functioning (e.g. carbon transformation and sequestration, regulation of microbial activity or community structure, nutrient turnover, aggregation). Consequently, soil invertebrates contribute to the provision of many ecosystem services such as nutrient cycling or soil structure maintenance (Lavelle, Decaëns, Aubert, Barot, Blouin et al. 2006; Barrios 2007; Kibblewhite, Ritz \& Swift 2008).

Studying soil invertebrate responses to environmental changes is of great interest. In various research fields (e.g. plant ecology), functional components of communities have revealed valuable insights into the understanding of organisms' responses to the environment (McGill, Enquist, Weiher \& Westoby 2006; Garnier \& Navas 2012). Originally, taxa were grouped into a priori functional groups based on certain "characteristics” which they shared. The classification into such functional groups is based on subjective expert judgment. For instance, several plant functional types existed, based on their life form or growth form (Lavorel, McIntyre, Landsberg \& Forbes 1997). Conclusions were drawn from these a priori functional groups’ richness (Villéger, Mason \& Mouillot 2008). However these approaches led to several limitations (Villéger et al. 2008) such as (i) a loss of information by imposing a discrete structure on functional differences between taxa, which are usually continuous (Gitay 
145 \& Noble 1997; Fonseca \& Ganade 2001), (ii) a non-robust way of obtaining results depending

146 on the choice of the functional group types in the analysis (Wright, Naeem, Hector, Lehman,

147 Reich et al. 2006) and sometimes (iii) a failure to take account of abundance (Díaz \& Cabido

148 2001). As an alternative to the taxonomic and a priori functional group approaches, trait-

149 based approaches have been developed (Lavorel \& Garnier 2002; McGill et al. 2006). Traits

150 can be divided into response and effect traits. An effect trait is an individual property which

151 affects an upper level of organization (e.g. ecosystem processes). Response traits, also called

152 functional traits, are properties of individuals which govern their responses to their

153 environment (Statzner, Hildrew \& Resh 2001; Violle, Navas, Vile, Kazakou, Fortunel et al.

154 2007). In the following, traits will mean response traits. Unlike a priori functional groups,

155 trait-based approaches are based on objective relations between individual properties (= traits)

156 and the environment. In other research fields, notably for plants, trait-based approaches have

157 brought several new insights to the understanding of organisms' responses to environmental

158 changes, by improving predictability and reducing context dependence (Webb, Hoeting,

159 Ames, Pyne \& LeRoy Poff 2010; Garnier et al. 2012). Prediction involves that a relationship

160 must be found between soil invertebrates and environmental changes through their traits. It

161 has been demonstrated that community assembly mechanisms are governed by rules. The

162 literature tends to support the existence of environmental filters which filter a sub-set of

163 individuals of the regional pool to form local communities (Keddy 1992; McGill et al. 2006).

164 Furthermore, environmental filters can be categorized according to the scale on which they

165 work. From larger scales to smaller ones, filters are (i) dispersal filters which select

166 individuals according to their dispersal capacity, (ii) abiotic filters which select individuals

167 according to their capacity to live under certain abiotic conditions and (iii) biotic filters which

168 represent the selection resulting from the interactions between individuals (Belyea \&

169 Lancaster 1999; Garnier et al. 2012). Reducing context dependency implies that trait-based 
170

171

172

173

174

175

176

177

178

179

180

181

182

183

185

186

187

188

189

190

191

192

193

194

approaches have to be: (i) generic over eco-regions and (ii) reliable whatever kind of

environmental change is considered. Enough trait-based approach studies have been made on plants to associate one or more traits with one or more environmental changes in any ecoregion (Garnier et al. 2012). For instance, “leaf area” responds gradually to complex environmental change such as climate change over eco-regions (Thuiller, Lavorel, Midgley, Lavergne \& Rebelo 2004; Moles, Warton, Warman, Swenson, Laffan et al. 2009).

To our knowledge, attempts to relate terrestrial invertebrate responses in terms of their “characteristics” to environmental stress began at the end of the ninetieth century (Statzner et al. 2001). In 1880, Semper (in Statzner et al. 2001) assessed the temperature-induced switch from parthenogenetic to sexual reproduction in aphids. During the following years, authors were convinced that environmental stress and "characteristics" of terrestrial insects were linked (Shelford 1913; Buxton 1923; Hesse 1924; Pearse 1926 - all in Statzner et al. 2001). For instance, Buxton (1923 - in Statzner et al. 2001) related “characteristics” of terrestrial insects such as the presence of wings or the tolerance of larvae to a lack of food and water to harsh environmental conditions of deserts (e.g. drought, torrential rain, whirlwinds).

Despite this early interest, no clear conceptual and methodological overview has been made for such "characteristics” of soil invertebrates, which are now called traits. Originally, as for plants, most previous studies assessed soil invertebrate responses to their environment using taxonomic structure and/or composition of communities. As soil invertebrate taxonomic diversity is huge, authors tried to simplify it by grouping together individuals by shared properties. The grouping also dealt with the lack of knowledge of taxonomy. For instance, eco-morphological groups, such as epigeic, anecic and endogeic groups of earthworms (Bouché 1972), epiedaphic, hemiedaphic and euedaphic groups of springtails (Gisin 1943) or terrestrial isopods (Schmallfuss 1984) and functional guilds such as the distinction between ecosystem engineers, litter transformers and micropredators (Lavelle \& Spain 2001) were 
195

196

197

198

199

200

201

202

203

204

205

206

207

208

209

210

211

212

213

214

215

216

217

218

219

used. For instance, eco-morphological groups bring together individuals based on subjective expert judgments of some of the ecological or biological "characteristics" they share. For instance, epigeic earthworms are pigmented and live near the soil surface, whereas endogeic earthworms are unpigmented and live deep in the soil. As for plants, all of these groupings have been used as a priori functional groups and should present the same disadvantages (see above). Experience in other research fields led us to think that using functional trait-based approaches for soil invertebrates represents one of the main opportunities to bring new insights into the understanding of soil invertebrate responses to the environment.

To our knowledge, no attempt has been made to clearly define functional trait concepts for soil invertebrates. The concept already existed but was used in other research fields. As a consequence, we first determine whether the actual definitions around the notion of traits are applicable to soil invertebrates. Second, to summarise the current advances in the understanding of soil invertebrate responses to the environment through their traits, a onedecade literature review was made. It also aimed to focus on current methodological advantages and drawbacks of soil invertebrate trait-based approaches. The last part envisages solutions and prospects for overcoming current conceptual and methodological drawbacks. It notably deals with the development of eco-informatics tools.

\section{Are existing trait definitions applicable to soil invertebrates?}

From work on terrestrial plants (Lavorel, Díaz, Cornelissen, Garnier, Harrison et al. 2007) or aquatic invertebrates (Bonada, Prat, Resh \& Statzner 2006), traits are being defined as properties of organisms measured at the individual level (Violle et al. 2007). Furthermore, a trait is qualified as "functional” when it influences the organism’s performance and consequently its fitness (Southwood 1977; Nylin \& Gotthard 1998; Blanck, Tedesco \& Lamouroux 2007; Violle et al. 2007; Webb et al. 2010). Some authors distinguish the 
220

221

222

223

224

225

226

227

228

229

230

231

232

233

234

235

236

237

238

239

240

241

242

243

244

performance traits from morphological, phenological and physiological traits (“M-P-P” traits).

Performance traits describe growth, reproduction and survival, considered as being the three components of fitness (Arnold 1983; McGill et al. 2006; Violle et al. 2007). Three main performance traits are recognized in plant ecology: vegetative biomass, reproductive output and measured plant survival (Violle et al. 2007). Conversely, "M-P-P” traits are supposed to influence fitness indirectly by influencing performance traits. In addition, plant abiotic preferences are denominated “Ellenberg’s numbers” and reflect optima/ranges in environmental gradients (Ellenberg 1988). In aquatic invertebrate ecology, traits are usually split into biological and ecological traits (Dolédec, Statzner \& Bournard 1999). Biological traits include M-P-P and life-history traits, while ecological traits reflect behaviour and ecological optima/ranges in environmental gradients.

Regarding soil fauna, many functional traits considered in the literature are related to morphology, physiology or phenology (Ribera, Doledec, Downie \& Foster 2001; Barbaro \& van Halder 2009; Vandewalle, de Bello, Berg, Bolger, Dolédec et al. 2010; Pérès, Vandenbulcke, Guernion, Hedde, Beguiristain et al. 2011) matching the definition proposed by Violle et al. (2007). The literature used, for instance, carabid beetle eye diameter or wing form for morphology, carabid beetle breeding season for phenology (Ribera et al. 2001; Vandewalle et al. 2010) or springtail reproductive mode for physiology (Malmstrom 2012). However, behaviour, such as “hunting strategy” (Langlands, Brennan, Framenau \& Main 2011), is a crucial component in animal fitness that was not taken into account in Violle’s definition as the definition was stated for plants. For animals other than soil invertebrates, behaviour was semantically included (i) in a "biological traits” group , (ii) in an "ecological traits” group or (iii) in a semantically dedicated “behavioural traits” group (Relya 2001; Bonada, Dolédec \& Statzner 2007; Frimpong \& Angermeier 2010). Behaviour can be defined as an organized and directed biological response to variations in the environment to suit the 
245 individual's requirements (adapted from (Barnard 2004))). The environment refers both to the

246 biocenosis and the biotope. We propose to extend Violle et al.’s (2007) definition of a

247 functional trait for soil invertebrates as follows: "any morphological, physiological,

248 phenological or behavioural (MPPB) feature measurable at the individual level, from the cell

249 to the whole-organism level, without reference to any other level of organization” (Table 1).

250 Furthermore, as for plants, we can distinguish MPPB traits from performance traits. The

251 performance traits for soil invertebrates could be for instance: biomass, offspring output and

252 measured survival. Population parameters can be derived from the median, mean and/or

253 breadth of distribution of a trait (aggregated values of a MPPB or a performance trait, Table

254 1).

255 In addition, some of the functional traits used in the literature refer to properties of the

256 environment in which individuals of a given species live. For instance, authors used the term

257 “soil moisture preferences” (Makkonen, Berg, van Hal, Callaghan, Press et al. 2011) to

258 express the breadth of the occurrence distribution of individuals of a species along a soil

259 moisture gradient. We propose to call "ecological preference” any value which results from

260 the optimum and/or the breadth of distribution of a trait along an environmental gradient

261 (Table 1).

262 Finally, authors called "life-history traits" (Stearns 1992) or "life-cycle traits" a wide range of 263 data such as moisture preference (Bokhorst, Phoenix, Bjerke, Callaghan, Huyer-Brugman et

264 al. 2012), adult daily activity (Barbaro et al. 2009) or body size estimated for a species

265 (Malmstrom 2012). Life-history traits need to be renamed, depending on their nature. In our

266 examples, moisture preference will be classified as an "ecological preference”, while adult

267 daily activity and body size estimated for a species are "population parameters derived from a 268 trait”.

269 Trait-based approaches for soil invertebrate community ecology 


\section{Methods for literature review}

A literature review was made from the ISI Web of Knowledge research platform using the search terms "trait” and "soil” or "ground" with each vernacular or taxonomic name of four groups: earthworms, ground beetles, spiders and springtails. The taxonomic groups were chosen because they represent a wide range of biological strategies and were often used as bio-indicators. Papers were selected according to several criteria described below. The term “trait” must have directly concerned soil invertebrates. To keep the scope of our study as restricted as possible, we only selected studies dealing with the effects of environmental changes on soil invertebrates. We did not include approaches exclusively dealing with other ecological questions or dedicated to evolutionary questions (e.g. adaptation, speciation). However, we are aware that ecological and evolutionary questions can overlap, notably when considering links between phylogeny and trait conservation (Cavender-Bares, Kozak, Fine \& Kembel 2009). Reviews (with no original data) and methodological papers were excluded. Searches were limited to papers published since 2000 as the use of the term "trait" in soil invertebrate ecological studies is quite recent. We may have failed to find some papers as the word "trait” was not used in some papers even though a trait-based approach was used. This highlights the fact that the trait concept suffers from semantic inconsistency for soil invertebrates as stated in the previous section. However, we chose to look for literature on measurable criteria (as mentioned above), especially by using the search word "trait", rather than on studies based on expert knowledge, even though this meant excluding a considerable number of papers. For instance, some studies using a trait-based approach have not been collected, e.g. for carabid beetles (Vanbergen, Woodcock, Koivula, Niemelä, Kotze et al. 2010), springtails (Ponge, Dubs, Gillet, Sousa \& Lavelle 2006), earthworms (Jimenez, Decaëns \& Rossi 2012), spiders (Lambeets, Vandegehuchte, Maelfait \& Bonte 2008; Le Viol, Julliard, Kerbiriou, de Redon, Carnino et al. 2008; Lambeets, Vandegehuchte, Maelfait \& 
Bonte 2009; Cristofoli, Mahy, Kekenbosch \& Lambeets 2010) and for multiple groups (Bell,

Mead, Skirvin, Sunderland, Fenlon et al. 2008; Jennings \& Pocock 2009; Moretti \& Legg

297

2009; De Lange, Lahr, Van der Pol \& Faber 2010; Hedde, van Oort \& Lamy 2012). However,

298

we are confident in the representativeness of the literature review, which found 4, 17, 4 and 6

299

papers for earthworms, ground beetles, spiders and springtails respectively (Table 2).

Scientific advances and drawbacks

301

All the literature showed, as for other research fields, that some environmental filters filter a

sub-set of individuals from a regional pool to form local communities according to some of

303

their traits. Most of the studies were dedicated to assess soil invertebrate response to some

kind of stress (Table 2). For instance, Barbaro et al. (2009), Driscoll et al. (2005) and Ribera

et al. (2001) assessed mechanisms of carabid beetle responses to habitat types according to

their traits (e.g. body size, wing development, Table 2). Underlying mechanisms of assembly

rules were sometimes assessed. For instance, Decaëns et al. (2008) demonstrated that some

abiotic environmental filters led to a trait convergence for earthworms. Decaëns et al. (2011)

309

revealed that the variability of morphological earthworm traits was lower in the regional

species pool and higher in the local species pool compared to what would have been expected

311 by chance. As very few examples were given, such patterns cannot be used as general patterns

312 for soil invertebrate assembly rules. However, the patterns described seemed to be similar to

313 those described in the introduction for other research fields. These results claimed that soil

314 invertebrate trait-based approaches help to improve predictability of community assembly in

315 relation to environmental changes as they materialise relationships between traits and

316 environmental changes.

317 Almost all of the studies assessed the responses of soil invertebrates in relation to only one

318 kind of environmental change. Some exceptions were found. For instance, Gobbi et al. (2010)

319 aimed to assess both the abiotic effect of deglaciation and the biotic effect of plant 
320

321

322

323

324

325

326

327

328

329

330

331

332

333

334

335

336

337

338

339

340

341

342

343

344

communities on carabid beetle communities. While individual studies usually dealt with a single change, environmental changes studied were diverse among studies. They included "natural” changes such as habitat type, fire, flooding or climatic events and also "anthropic" changes such as invasive tree species or human practices on cultivated fields or forests (Table 2). In addition, studies were geographically limited to the regional scale (sensu Belyea et al. 1999). Some exceptions occurred, e.g. Vandewalle et al. (2010) who sampled carabid beetles in several European countries. They assumed that the responses of functional diversity indices calculated from traits (e.g. Rao index of diversity, Botta-Dukat 2005) to habitat composition and landscape heterogeneity were consistent across geographical regions.

To conclude, we cannot be confident in trait genericity over eco-regions, as this was rarely studied (Vandewalle et al. 2010). Despite these shortcomings in reducing the context dependence, the literature currently gives us some insights as to which traits might be more useful than others to respond to a particular kind of environmental change. For instance, it has been shown that ground beetle wing development varies with habitat type in different contexts (Ribera et al. 2001; Driscoll \& Weir 2005; Gobbi \& Fontaneto 2008; Barbaro et al. 2009; Gobbi, Caccianiga, Cerabolini, Bernardi, Luzzaro et al. 2010; Vandewalle et al. 2010). To make the trait-based approaches reliable whatever the kind of environmental changes, we have to establish relationships between each kind of environmental change with one or several traits.

\section{Methodological advantages and drawbacks}

Complementarity with other approaches

From a methodological point of view, trait-based approaches bring new insights into the understanding of soil invertebrate responses to stress, compared to taxonomic approaches (Cole, McCracken, Dennis, Downie, Griffin et al. 2002; Gobbi et al. 2008; Langlands et al. 2011). First, inverse trends between results obtained by trait-based and taxonomic approaches 
345

346

347

348

349

350

351

352

353

354

355

356

357

358

359

360

361

362

363

364

365

366

367

368

369

were reported. For example, Gerisch, Agostinelli, Henle \& Dziock (2012) showed that the species diversity of ground beetle communities increased whereas functional diversity (functional evenness and divergence) decreased with increasing flooding disturbances. This combined approach led the authors to conclude that flooding disturbance increased the number of species but that species were functionally redundant. Otherwise, Gobbi et al. (2008) showed that ground beetle traits such as wing morphology, diet and body size responded to habitat diversity, while species richness and a taxonomic diversity index based on phylogeny did not. The authors therefore claimed that trait-based approaches should be favoured for assessing mechanisms of carabid beetle responses to habitat disturbance rather than taxonomic approaches. In other cases, trait-based approaches complemented the conclusions based on taxonomic approaches. For instance, in a study by Fournier, Samaritani, Shrestha, Mitchell \& Le-Bayon (2012), community-weighted means of earthworm traits (e.g. body length and width, pH optimum and range) were more strongly correlated with environmental variables (e.g. total carbon, gravel sizes, type of cover, such as mosses, woody debris) than species composition and taxonomic diversity. However, no study aimed at comparing approaches based on a priori functional groups (e.g. eco-morphological groups) with trait-based approaches.

Deficiencies in trait definitions, data treatment and gathering structure

The literature review revealed semantic inconsistencies for trait names. For instance, the type of materials eaten by soil invertebrates (e.g. carnivorous) and the way they feed on them (e.g. as predators, i.e. by killing their preys). However, the literature revealed several categorical traits whose attributes could describe several of the above concepts simultaneously. For instance, "food of the adult" (Cole et al. 2002; Ribera et al. 2001) referred both to the type of food eaten (e.g. plant, springtails) but also to the way it was eaten (e.g. generalist predators) whereas “diet” (Barbaro et al. 2009) refers only to the first one. Such drawbacks occurred 
370

371

372

373

374

375

376

377

378

379

380

381

382

383

384

385

386

387

388

389

390

391

392

393

394

within a taxon but also among taxa. They can hinder data gathering in so far as they can cast doubt on a trait's scientific meaning.

At the moment, soil invertebrate trait-based approaches used traits at the species level. Such a process can lead to two main biases. A first bias occurs when the trend of the relationship between the mean trait of $\mathrm{N}$ species and an environmental gradient is in the opposite direction to the relationships between this environmental gradient and individual trait values. The second bias is that using traits at the species level hides individual heterogeneity.

Traits can be described in two formats, numerical data (e.g. eye diameter, (Ribera et al. 2001)) or by text (e.g. pigmentation, wing form, (Vandewalle et al. 2010)). Format heterogeneity and the missing data impeded the use of traits. It has been suggested that traits should be encoded into a limited number of subsets (Chevenet, Dolédec \& Chessel 1994; Hedde et al. 2012). For all of these reasons, some authors discretized data into attributes, e.g. by fuzzy coding procedures (e.g. body size classes, (Jelaska, Jesovnik, Jelaska, Pirnat, Kucinic et al. 2010) or diet, (Pérès et al. 2011). When working on one or several taxonomic groups, it was crucial to be able to deal with different data formats. However when this was done, the way data were transformed by fuzzy coding was not clearly explained. This impedes the comparison between studies using a trait shared by one or several groups but not necessarily using the same coding procedure (e.g. different categories for the diet) (Barbaro et al. 2009; Gerisch 2011). It also limits the reuse of an encoded trait from the literature as readers do not know exactly how the trait was encoded.

Exploiting existing literature was preferred to time-consuming trait measurements on sampled specimens. Whatever the methodology, the review of literature underlined the lack of a datacompilation structure for soil invertebrate traits. Depending on the author, a trait could be described from different literature sources. Cole et al. (2002) and Karen, O'Halloran, Breen, Giller, Pithon et al. (2008) described body size trait values for Nebria brevicollis (Fabricius) 
from two different literature sources. As a consequence, works do not benefit each other as no

396 data-compilation allows authors to have access on existing trait data.

397 A general shortcoming which is not often considered in the current literature is the fact that

398

399

400

401

402

403

404

405

406

407

408

409

410

411

412

413

414

415

416

417

418

419

traits used in a study can be inter-correlated ("trait syndromes") (Poff, Olden, Vieira, Finn,

Simmons et al. 2006). Inter-correlation can therefore cause that traits appear decoupled from environmental changes (Statzner, Dolédec \& Hugueny 2004; Poff et al. 2006). Generally, trait selection for analyses was a priori justified on the basis of the biological function they are supposed to be linked with. For instance, (Langlands et al. 2011) selected the body shape of spiders, as spiders with flattened bodies are supposed to shelter better from fire. Apart from this view, no analysis has been described to identify “trait syndromes” before performing linking traits to environmental variables. Exception was made for certain studies (Gobbi et al. 2008).

\section{Future needs: eco-informatics at a crossroad}

The following prospects are not limited to the four taxa used in the literature search. They are suitable for all the soil invertebrate taxa. Large amounts of data from multiple data sources need to be characterized and integrated into a unified corpus in order to improve soil invertebrate trait-based approaches. Current eco-informatics literature provides a basis for a global scheme to structure ecological data (Madin, Bowers, Schildhauer, Krivov, Pennington et al. 2007; Garnier et al. 2012). Between non-robust data storage by scientists (e.g. spreadsheets, relational database systems) (Jones, Schildhauer, Reichman \& Bowers 2006) and their exploitation by software tools (e.g. "R Statistical Package") (R Development Core Team 2010), an intermediate level is needed. It requires linking data with metadata, which are information used to document and interpret data (Jones et al. 2006). Such a level would greatly enhance data management (storage, integrating, querying, and analysing) by producing robust traceability. One way is to construct a database management system 
420 (DBMS) for soil invertebrate traits which could associate metadata with data. First are

421 "scientific" metadata describing scientific data (e.g. information usually provided in the

422 Materials and methods section). Scientific metadata provide all the necessary information for 423 acquiring, interpreting and using scientific data. Second are "computer” metadata required for 424 computerisation (e.g. metadata required for the database structure, semantic metadata). They 425 principally allow acquisition and automated input, analysis and processing of scientific data 426 by the computer (Michener 1997; Michener 2006). Associating data to metadata in a DBMS 427 provides several advantages. Data longevity (data history) and quality (control of the nature of 428 data) are increased. Data could be easily reused and integrated. Finally data sharing is 429 facilitated (Jones et al. 2006; Michener 2006). DBMS per se possesses sorting, indexing and querying functions which increase data interpretation and use (Porter 1998). A few databases 431 for soil invertebrates already exist: for instance, Edaphobase (Russell, Vorwald, Franzke, 432 Höfer, Horak et al. 2012), Coltrait (Salmon \& Ponge 2012), the Dutch soil invertebrate trait 433 database (from M.P. Berg) (Makkonen et al. 2011), Macrofauna (Lapied, personal 434 communication), and Ant Profiler (Bertelsmeier, Luque, Confais \& Courchamp 2012). 435 Nevertheless, they do not always contain trait data or are not always in a format which allows 436 collaborative data sharing. Even if they fulfil such criteria, they tend to be concerned with a 437 small part of the whole diversity of soil invertebrates (usually a single group is concerned). 438 Computer science solutions currently exist to gather data from different sources (Jones et al. 439 2006; Michener 2006), so previous soil invertebrate databases should not be seen as isolated 440 islands (Jones et al. 2006) but as complementary bricks which can be combined to create new 441 soil invertebrate trait databases. However, combining data from different formats, especially 442 from spreadsheets, is not easy (Jones et al. 2006).

443 Among the existing solutions, semantic data integration is a promising way which preserves 444 the scientific meaning of data. Semantic approaches deal with the differences in the terms 
445 used (terminology) and the scientific concepts formulated by soil invertebrate experts over

446 time (Madin et al. 2007; Laporte, Mougenot \& Garnier 2012). To achieve this, the soil

invertebrate scientific community is required to standardize meaningful and precise terms that

cover their domain of interest. Trait names are especially concerned, taking a central position

in trait-based approaches in the context of the responses of soil invertebrates to their

environment. A thesaurus of a particular domain reflects a community agreement on a set of

terms established in a given area and its organization through a well-designed structure.

452 Furthermore, a thesaurus is recognized as a knowledge organization system and bypasses

453 ambiguity issues in natural language, controlling and clarifying the access and exchange of

454 information and facilitating communication. The main concern focuses on access, sharing and

dissemination of information within the soil invertebrate scientific community. First, a soil

invertebrate trait thesaurus can serve as a stable reference resource, specifically when

published in RDF (Resource Description Framework) language (Manola \& Miller 2004) and

available as linked data on the web. A second prospect is to include such a thesaurus in soil

459 invertebrate trait databases to facilitate data management. A third, more long-term prospect, involves the use of the thesaurus as a prerequisite for the construction of a soil invertebrate trait ontology. To conclude, it would be of major assistance for the soil invertebrate scientist community to have access to knowledge-based models enabling the efficient answering of questions, which, for example, may require the data aggregation of different traits from

464 several taxa.

465 Effort on data management using eco-informatics tools will fill some gaps revealed by the 466 literature review. First, it will strengthen current scientific advances. By increasing the 467 collection of trait data and associated environmental parameters, it will offer the possibility of 468 considering the actions of several environmental filters on different spatial and temporal 469 scales (see section “Scientific advances and drawbacks”). It will also aim to establish 
470

471

472

473

474

475

476

477

478

479

480

481

482

483

484

485

486

487

488

489

490

491

492

493

494

consistent “population parameters derived from traits” and “ecological preferences” (Table 1)

by increasing the number of literature sources informing trait values used to calculate them.

All of this will contribute to a better general understanding of soil invertebrate responses to the environment from local to biogeographical scales, which was not always possible from independent single studies. The data gathering structure should also improve knowledge of soil invertebrate group interactions, since it will become possible to work on several groups and taxa with several comparable traits.

Second, it will help with some methodological shortcomings. It will improve the possibility of dealing with (i) inter-correlation of traits and (ii) bias when using traits on the species level (see section “Deficiencies in trait definitions, data treatment and gathering structure”). On the one hand (i), "trait syndromes” could be more easily revealed because the data gathering structure should provide a large body of available documented traits. We recommend testing for inter-correlation of traits before drawing conclusions (e.g. fuzzy correspondence analysis, “ade4” R package, (Chessel, Dufour \& Thioulouse 2004)). One other solution which has not been tested for soil invertebrates since not enough trait data have yet been gathered, is the screening method (Bernhardt-Römermann, Römermann, Nuske, Parth, Klotz et al. 2008). This allows the best combination of traits to be found for an environmental change. On the other hand (ii), with the increasing number of trait values measured on individuals rather than compiled at species or higher taxonomic level, it will provide the opportunity to put much more intraspecific variability into the assessment of functional diversity. It is a way to overrule bias when using traits at a species level.

Although the data gathering structure will enable the collection of data documenting traits from all sources (e.g. articles, books) and from all formats, i.e. numerical data (e.g. body size distribution) and literal data (e.g. text descriptions of diets), it will not deal with the definition of similar fuzzy coding protocols (see section "Deficiencies in trait definitions, data treatment 
495 and gathering structure”). For instance, we propose two main protocols: one for traits

496 described by numerical values and another for traits described by textual data (see Appendix

497 A).

498

\section{Acknowledgements}

500 The authors wish to thank the CESAB (Centre de Synthèse et d'Analyses sur la Biodiversité)

501 and the FRB (Fondation pour la Recherche sur la Biodiversité) for their financial support. We

502 also thank Baptiste Laporte (FRB/CESAB) for his advice on computer science. Finally, we

503 kindly thank M. Berg and three anonymous reviewers for greatly improving the scientific

504 content of the manuscript through their comments.

505 


\section{Tables}

506 Table 1. Definitions of trait concepts for soil invertebrates.

507
Concept
Definitions
MPPB trait
Any morphological, physiological, phenological or behavioural (MPPB) feature measurable at the individual level, from the cell to the whole-organism level, without reference to any other level of organization
Performance trait
Performance traits describe growth, reproduction and survival, considered as being the three components of fitness (Violle et al. 2007). For soil invertebrates there are for instance: biomass, offspring output and survival
Ecological preference
The optimum and/or the breadth of distribution of a trait on an environmental gradient.
Population parameters
The median, mean and/or breadth of distribution of a trait (aggregated values of a derived from traits MPPB or a performance trait). 
Table 2. Results of the literature review and some of the properties of the selected articles. LIT: trait data from the literature, OMS: original measurements of traits. Without any specific information, we assumed that trait data had been derived from the literature.

\section{Reference}

Decaëns et al. (2011)

Decaëns et al. (2008)

Fournier et al. (2012)

Pérès et al. (2011)

Bonte et al. (2006)

Buchholz (2010)

Earthworms

\section{OMS}

change

Habitat (differen aged pastures)

Habitat

Flooding

Contamination and land use

Spiders Sand dynamics

Spiders

Climate (drought)

\section{LIT}

LIT

LIT +

OMS

LIT

LIT +

LIT +

OMS

\section{Traits}

(Ecological category), body length, diameter, weight, epithelium type, pigmentation

Size, weight, pigmentation,

(ecological categories, ecological features)

Length, width, weight, segment number, $\mathrm{pH}$ optimum, $\mathrm{pH}$ range, prostomium type, (ecological type), C/N (soil) preference Body pigmentation, body wall thickness, food, reproductive strategy, rarity

Mean size, local activity-density, niche breath, ballooning, seasonal activity, generation time, diurnal activity

\section{Burrowing, body size} (length),cephalothorax heavy sclerotisation, abdominal scutes, ballooning, time to maturity, phenology, hunting strategy, diet specialization (ants), flattened body

Climate (winter
warming)

Langlands et al. (2011)

Spiders

Fire

\section{Tropek et al. (2008)}

Spiders

Stone quarry

\section{LIT +}

$$
\text { OMS }
$$

Bokhorst et al. (2012)
Springtails 
Huebner et al. (2012)

Lindberg \& Bengtsson (2005)

Makkonen et al. (2011)

Malmstrom (2012)

Vandewalle et al. (2010)

Barbaro et al. (2009)

Cole et al. (2002)

Driscoll et al. (2005)

Gerisch et al. (2012)

Gerisch (2011)
Ground beetles

(fragmentation)

Springtails

Fire

Springtails

Climate (drought)

Climate

Fire

Invasive tree

species

Springtails

Habitat

Ground beetles

(agricul

management)

Habitat

Ground beetles

Ground beetles

Flooding

Ground beetles

Flooding
LIT

LIT

LIT +

OMS

LIT

LIT +

OMS

LIT

LIT

LIT
Dente shape, eye number, total body length, furcula, pigmentation, body scales, PAO, antennae length, antennal organ, sexual dimorphism

Depth distribution, reproductive mode, habitat specialization,

(ecological category)

Ocelli number, body size, body pigmentation level, body

pigmentation pattern, modified

hairs or scales, furca development, antenna/body, moisture preference, habitat width

Habitat (vertical stratification), body size, reproductive mode, dispersal traits

Ocelli, antenna length, furca, hairs/scales, pigmentation

European trend, European rarity, regional rarity, biogeographic position, daily activity, diet, overwintering, body colour, breeding season, body size (mm), wing development, adult activity period

Size (length), overwintering, life cycle duration, adult food, daily activity, breeding season, emergence, main activity, wing morphology, locomotion

Flight, trophic group, adult primary position, size

Wing morphology, overwintering strategy (reproduction season), body size

Body size, wing morphology, reproduction period, overwintering stage, daily activity, colour elytra, 
Gobbi et al. (2010)

Gobbi et al. (2008)

Grimbacher \& Stork (2009)

Jelaska et al. (2010)

Karen et al. (2008)

Liu et al. (2012)

Ribera et al. (2001)

Ground beetles

Habitat (land disturbance)

Ground beetles

Habitats (orchard and riparian)

Ground beetles

Ground beetles

Deglaciated terrain and plants

Ground beetles Habitat

\section{Climate} (seasonality)

Habitat (natural temperate forests)

Habitat (forest cycle plantation)

Habitat (human practices on seminatural habitats and cultivated fields)

\section{Silva et al. (2011)}

Tropek et al. (2008)

Vandewalle et al. (2010)

\section{Stone quarry}

\section{Habitat} (composition and
LIT +

OMS

Brachypterous, autumn-breeding, predators, average body length Wing morphology, body length, diet

Feeding ecology, body size, habitat strata, mean period of activity Body size

Broad habitat associations, body size, wing-type, microhabitat associations

\section{LIT \&}

OMS

Trophic status, body size

Eye diameter, antenna length, pronotum maximum width, pronotum maximum depth, elytra maximum width, metafemur length, metatrochanter length, metatarsi length, metafemur maximum width, total length, leg color, body color, wing development, pronotum shape, overwintering, adult food, daily activity, breeding season, main period of adult emergence, main period of adult activity

\section{Moisture preferences}

Wing form, body pubescence, body length, elytra width, elytra 


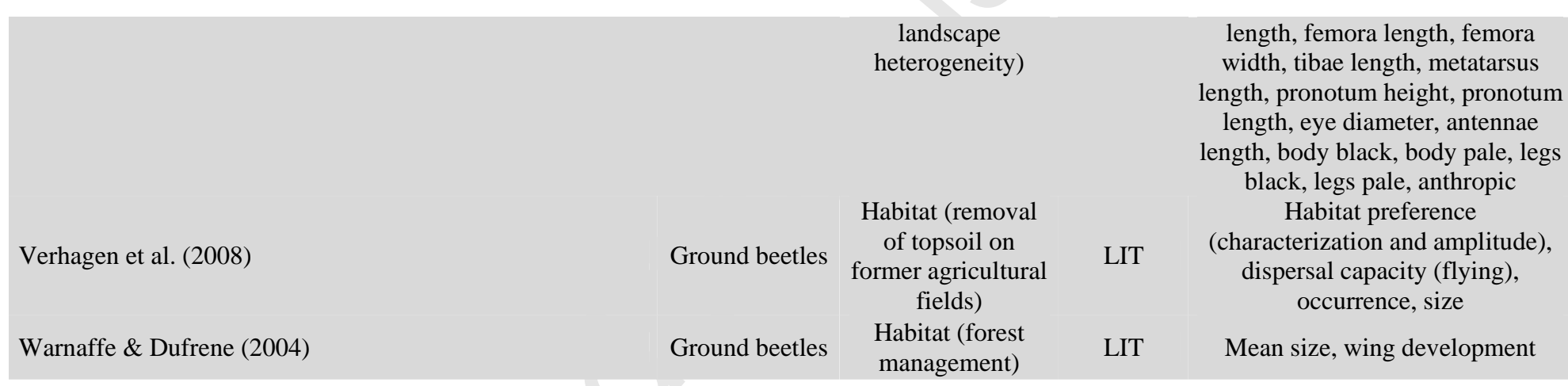


519

520

521

522

523

524

525

526

527

528

529

530

531

532

533

534

535

536

537

538

539

540

541

542

543

544

545

546

547

548

549

550

551

552

553

554

555

556

557

558

559

\section{References}

André, H.M., Noti, M.I., \& Lebrun, P. (1994). The Soil Fauna - the Other Last Biotic Frontier. Biodiversity and Conservation, 3, 45-56.

Arnold, S.J. (1983). Morphology, Performance and Fitness. American Zoologist, 23, 347-361.

Barbaro, L., \& van Halder, I. (2009). Linking bird, carabid beetle and butterfly life-history traits to habitat fragmentation in mosaic landscapes. Ecography, 32, 321-333.

Barnard, C.J. (2004). Animal Behaviour: Mechanism, Development, Function, and Evolution.

Barrios, E. (2007). Soil biota, ecosystem services and land productivity. Ecological Economics, 64, 269-285.

Bell, J.R., Mead, A., Skirvin, D.J., Sunderland, K.D., Fenlon, J.S., \& Symondson, W.O.C. (2008). Do functional traits improve prediction of predation rates for a disparate group of aphid predators? Bulletin of Entomological Research, 98, 587-597.

Belyea, L.R., \& Lancaster, J. (1999). Assembly rules within a contingent ecology. Oikos, 86, 402-416.

Bernhardt-Römermann, M., Römermann, C., Nuske, R., Parth, A., Klotz, S., Schmidt, W., \& Stadler, J. (2008). On the identification of the most suitable traits for plant functional trait analyses. Oikos, 117, 1533-1541.

Bertelsmeier, C., Luque, G.M., Confais, A., \& Courchamp, F. (2012). Ant Profiler - a database of ecological characteristics of ants (Hymenoptera: Formicidae). Myrmecological News, 18, 73-76.

Blanck, A., Tedesco, P.A., \& Lamouroux, N. (2007). Relationships between life-history strategies of European freshwater fish species and their habitat preferences. Freshwater Biology, 52, 843-859.

Bokhorst, S., Phoenix, G.K., Bjerke, J.W., Callaghan, T.V., Huyer-Brugman, F., \& Berg, M.P. (2012). Extreme winter warming events more negatively impact small rather than large soil fauna: shift in community composition explained by traits not taxa. Global Change Biology, 18, 1152-1162.

Bonada, N., Dolédec, S., \& Statzner, B. (2007). Taxonomic and biological trait differences of stream macroinvertebrate communities between mediterranean and temperate regions: Implications for future climatic scenarios. Global Change Biology, 13, 1658-1671.

Bonada, N., Prat, N., Resh, V.H., \& Statzner, B. (2006). Developments in aquatic insect biomonitoring: A comparative analysis of recent approaches. Annual Review of Entomology (pp. 495-523). Palo Alto: Annual Reviews.

Bonte, D., Lens, L., \& Maelfait, J.P. (2006). Sand dynamics in coastal dune landscapes constrain diversity and life-history characteristics of spiders. Journal of Applied Ecology, 43, 735-747.

Botta-Dukat, Z. (2005). Rao's quadratic entropy as a measure of functional diversity based on multiple traits. Journal of Vegetation Science, 16, 533-540.

Bouché, M.B. (1972). Lombriciens de France. Ecologie et Systématique.

Buchholz, S. (2010). Simulated climate change in dry habitats: do spiders respond to experimental small-scale drought? Journal of Arachnology, 38, 280-284. 
Buxton, P.A. (1923). Animal Life in Deserts. London.

561

562

563

564

565

566

567

568

569

570

571

572

573

574

575

576

577

578

579

580

581

582

583

584

585

586

587

588

589

590

591

592

593

594

595

596

597

598

599

Cavender-Bares, J., Kozak, K.H., Fine, P.V.A., \& Kembel, S.W. (2009). The merging of community ecology and phylogenetic biology. Ecology Letters, 12, 693-715.

Chessel, D., Dufour, A.B., \& Thioulouse, J. (2004). The ade4 Package. $R$ News, 4, 5-10.

Chevenet, F., Dolédec, S., \& Chessel, D. (1994). A fuzzy coding approach for the analysis of long-term ecological data. Freshwater Biology, 31, 295-309.

Cole, L.J., McCracken, D.I., Dennis, P., Downie, I.S., Griffin, A.L., Foster, G.N., Murphy, K.J., \& Waterhouse, T. (2002). Relationships between agricultural management and ecological groups of ground beetles (Coleoptera : Carabidae) on Scottish farmland. Agriculture Ecosystems \& Environment, 93, 323-336.

Cristofoli, S., Mahy, G., Kekenbosch, R., \& Lambeets, K. (2010). Spider communities as evaluation tools for wet heathland restoration. Ecological Indicators, 10, 773-780.

De Lange, H.J., Lahr, J., Van der Pol, J.J.C., \& Faber, J.H. (2010). Ecological vulnerability in wildlife: Application of a species-ranking method to food chains and habitats. Environmental Toxicology and Chemistry, 29, 2875-2880.

Decaëns, T., Jimenez, J.J., Gioia, C., Measey, G.J., \& Lavelle, P. (2006). The values of soil animals for conservation biology. European Journal of Soil Biology (pp. S23-S38).

Decaëns, T., Margerie, P., Aubert, M., Hedde, M., \& Bureau, F. (2008). Assembly rules within earthworm communities in North-Western France-A regional analysis. Applied Soil Ecology.

Decaëns, T., Margerie, P., Renault, J., Bureau, F., Aubert, M., \& Hedde, M. (2011). Niche overlap and species assemblage dynamics in an ageing pasture gradient in north-western France. Acta Oecologica, 37, 212-219.

Díaz, S., \& Cabido, M. (2001). Vive la différence: plant functional diversity matters to ecosystem processes Trends in Ecology \& Evolution, 16, 646-654.

Dolédec, S., Statzner, B., \& Bournard, M. (1999). Species traits for future biomonitoring across ecoregions: patterns along a human-impacted river. Freshwater Biology, 42, 737-758.

Driscoll, D.A., \& Weir, T. (2005). Beetle responses to habitat fragmentation depend on ecological traits, habitat condition, and remnant size. Conservation Biology, 19, 182-194.

Ellenberg, H. (1988). Vegetation ecology of central Europe. (4th edition ed.).

Fonseca, C.R., \& Ganade, G. (2001). Species functional redundancy, random extinctions and the stability of ecosystems. Journal of Ecology, 89, 118-125.

Fournier, B., Samaritani, E., Shrestha, J., Mitchell, E.A.D., \& Le-Bayon, R.C. (2012).

Patterns of earthworm communities and species traits in relation to the perturbation gradient of a restored floodplain. Applied Soil Ecology, 59, 87-95.

Frimpong, E.A., \& Angermeier, P.L. (2010). Trait-Based Approaches in the Analysis of Stream Fish Communities. American Fisheries Society Symposium, 73, 109-136.

Garnier, E., \& Navas, M.L. (2012). A trait-based approach to comparative functional plant ecology: concepts, methods and applications for agroecology. A review. Agronomy for Sustainable Development, 32, 365-399. 
600 Gerisch, M. (2011). Habitat disturbance and hydrological parameters determine the body size 601 and reproductive strategy of alluvial ground beetles. Zookeys (pp. 353-370): PENSOFT

602 Publishers.

603 Gerisch, M., Agostinelli, V., Henle, K., \& Dziock, F. (2012). More species, but all do the 604 same: contrasting effects of flood disturbance on ground beetle functional and species 605 diversity. Oikos, 121, 508-515.

606 Giller, P.S. (1996). The diversity of soil communities, the 'poor man's tropical rainforest'. 607 Biodiversity and Conservation, 5, 135-168.

608 Gisin, H. (1943). Ökologie und Lebensgemeinschaften der Collembolen im Schweizerischen 609 Exkursionsgebiet Basels. Revue Suisse de Zoologie, 50, 131-224.

610 Gitay, H., \& Noble, I.R. (1997). What are functional types and how should we seek them? In: 611 H.H.S.F.I.W. T.M. Smith (Ed.), Plant Functional Types (pp. 3-19): Cambridge University 612 Press, Cambridge.

613 Gobat, J.-M., Aragno, M., \& Matthey, W. (1998). Le sol vivant, Bases de pédologie, Biologie 614 des sols.

615 Gobbi, M., Caccianiga, M., Cerabolini, B., Bernardi, F., Luzzaro, A., \& Pierce, S. (2010).

616 Plant adaptive responses during primary succession are associated with functional adaptations

617 in ground beetles on deglaciated terrain. Community Ecology, 11, 223-231.

618 Gobbi, M., \& Fontaneto, D. (2008). Biodiversity of ground beetles (Coleoptera: Carabidae) in 619 different habitats of the Italian Po lowland. Agriculture, Ecosystems \& Environment, 127,

$620 \quad 273-276$.

621 Grimbacher, P.S., \& Stork, N.E. (2009). Seasonality of a diverse beetle assemblage inhabiting 622 lowland tropical rain forest in Australia. Biotropica, 41, 328-337.

623 Hedde, M., van Oort, F., \& Lamy, I. (2012). Functional traits of soil invertebrates as 624 indicators for exposure to soil disturbance. Environmental Pollution, 164, 59-65.

625 Hesse, R. (1924). Tiergeographie auf oekologischer Grundlage. Jena: Fischer.

626 Huebner, K., Lindo, Z., \& Lechowicz, M.J. (2012). Post-fire succession of collembolan 627 communities in a northern hardwood forest. European Journal of Soil Biology, 48, 59-65.

628 Jelaska, L.S., Jesovnik, A., Jelaska, S.D., Pirnat, A., Kucinic, M., \& Durbesic, P. (2010).

629 Variations of carabid beetle and ant assemblages, and their morpho-ecological traits within 630 natural temperate forests in Medvednica Nature Park. Sumarski List, 134, 475-486.

631 Jennings, N., \& Pocock, M.J.O. (2009). Relationships between Sensitivity to Agricultural 632 Intensification and Ecological Traits of Insectivorous Mammals and Arthropods.

633 Conservation Biology, 23, 1195-1203.

634 Jimenez, J.J., Decaëns, T., \& Rossi, J.P. (2012). Soil environmental heterogeneity allows 635 spatial co-occurrence of competitor earthworm species in a gallery forest of the Colombian 636 'Llanos'. Oikos, 121, 915-926.

637 Jones, M.B., Schildhauer, M.P., Reichman, O.J., \& Bowers, S. (2006). The new 638 bioinformatics: Integrating ecological data from the gene to the biosphere. Annual Review of 639 Ecology Evolution and Systematics (pp. 519-544). Palo Alto: Annual Reviews.

640 Karen, M., O'Halloran, J., Breen, J., Giller, P., Pithon, J., \& Kelly, T. (2008). Distribution and

641 composition of carabid beetle (Coleoptera, Carabidae) communities across the plantation

642 forest cycle - implications for management. Forest Ecology and Management, 256, 624-632. 
643 Keddy, P.A. (1992). Assembly and response rules: two goals for predictive community 644 ecology. Journal of Vegetation Science, 3, 157-164.

645 Kibblewhite, M.G., Ritz, K., \& Swift, M.J. (2008). Soil health in agricultural systems. 646 Philosophical Transactions of the Royal Society B-Biological Sciences, 363, 685-701.

647 Lambeets, K., Vandegehuchte, M.L., Maelfait, J.P., \& Bonte, D. (2008). Understanding the 648 impact of flooding on trait-displacements and shifts in assemblage structure of predatory 649 arthropods on river banks. Journal of Animal Ecology, 77, 1162-1174.

650 Lambeets, K., Vandegehuchte, M.L., Maelfait, J.P., \& Bonte, D. (2009). Integrating 651 environmental conditions and functional life-history traits for riparian arthropod conservation 652 planning. Biological Conservation, 142, 625-637.

653 Langlands, P.R., Brennan, K.E.C., Framenau, V.W., \& Main, B.Y. (2011). Predicting the 654 post-fire responses of animal assemblages: testing a trait-based approach using spiders.

655 Journal of Animal Ecology, 80, 558-568.

656 Laporte, M.-A., Mougenot, I., \& Garnier, E. (2012). ThesauForm - Traits : a web based 657 collaborative tool to develop a thesaurus for plant functional diversity research. Ecological 658 Informatics.

659 Lavelle, P., Decaëns, T., Aubert, M., Barot, S., Blouin, M., Bureau, F., Margerie, P., Mora, P., 660 \& Rossi, J.P. (2006). Soil invertebrates and ecosystem services. European Journal of Soil 661 Biology, 42, S3-S15.

662 Lavelle, P., \& Spain, A.V. (Eds.). (2001). Soil ecology.

663 Lavorel, S., Díaz, S., Cornelissen, J., Garnier, E., Harrison, S., McIntyre, S., Pausas, J., Pérez664 Harguindeguy, N., Roumet, C., Urcelay, C., Canadell, J.G., Pataki, D.E., \& Pitelka, L.F. 665 (2007). Plant functional types: are we getting any closer to the Holy Grail? Terrestrial 666 ecosystems in a changing world. (pp. 149-164): Springer Berlin Heidelberg.

667 Lavorel, S., \& Garnier, E. (2002). Predicting changes in community composition and 668 ecosystem functioning from plant traits: revisiting the Holy Grail. Functional Ecology, 16, $669 \quad 545-556$.

670 Lavorel, S., McIntyre, S., Landsberg, J., \& Forbes, T.D.A. (1997). Plant functional 671 classifications: from general groups to specific groups based on response to disturbance.

672 Trends in Ecology \&amp; Evolution, 12, 474-478.

673 Le Viol, I., Julliard, R., Kerbiriou, C., de Redon, L., Carnino, N., Machon, N., \& Porcher, E. 674 (2008). Plant and spider communities benefit differently from the presence of planted 675 hedgerows in highway verges. Biological Conservation, 141, 1581-1590.

676 Lindberg, N., \& Bengtsson, J. (2005). Population responses of oribatid mites and 677 collembolans after drought. Applied Soil Ecology, 28, 163-174.

678 Liu, Y., Axmacher, J.C., Wang, C., Li, L., \& Yu, Z. (2012). Ground beetle (Coleoptera:

679 Carabidae) assemblages of restored semi-natural habitats and intensively cultivated fields in 680 northern China. Restoration Ecology, 20, 234-239.

681 Madin, J., Bowers, S., Schildhauer, M., Krivov, S., Pennington, D., \& Villa, F. (2007). An 682 ontology for describing and synthesizing ecological observation data. Ecological Informatics, 683 2, 279-296.

684 Makkonen, M., Berg, M.P., van Hal, J.R., Callaghan, T.V., Press, M.C., \& Aerts, R. (2011). 685 Traits explain the responses of a sub-arctic Collembola community to climate manipulation. 686 Soil Biology \& Biochemistry, 43, 377-384. 
687 Malmstrom, A. (2012). Life-history traits predict recovery patterns in Collembola species

688 after fire: a 10 year study. Applied Soil Ecology, 56, 35-42.

689 Manola, F., \& Miller, E. (2004). RDF Primer, W3C Recommendation.

690 McGill, B.J., Enquist, B.J., Weiher, E., \& Westoby, M. (2006). Rebuilding community

691 ecology from functional traits. Trends in Ecology \& Evolution, 21, 178-185.

692 Michener, W.K. (1997). Quantitatively evaluating restoration experiments: Research design,

693 statistical analysis, and data management considerations. Restoration Ecology, 5, 324-337.

694 Michener, W.K. (2006). Meta-information concepts for ecological data management.

695 Ecological Informatics, 1, 3-7.

696 Moles, A.T., Warton, D.I., Warman, L., Swenson, N.G., Laffan, S.W., Zanne, A.E., Pitman,

697 A., Hemmings, F.A., \& Leishman, M.R. (2009). Global patterns in plant height. Journal of

698 Ecology, 97, 923-932.

699 Moretti, M., \& Legg, C. (2009). Combining plant and animal traits to assess community

700 functional responses to disturbance. Ecography, 32, 299-309.

701 Nylin, S., \& Gotthard, K. (1998). Plasticity in Life-History Traits. Annual Review of

702 Entomology, 43, 63-83.

703 Pearse, A.S. (1926). Animal Ecology. New York.

704 Pérès, G., Vandenbulcke, F., Guernion, M., Hedde, M., Beguiristain, T., Douay, F., Houot, S.,

705 Piron, D., Richard, A., Bispo, A., Grand, C., Galsomies, L., \& Cluzeau, D. (2011). Earthworm

706 indicators as tools for soil monitoring, characterization and risk assessment. An example from

707 the national Bioindicator programme (France). Pedobiologia (pp. S77-S87). Munchen,

708 Germany: Elsevier GmbH.

709 Poff, N.L., Olden, J.D., Vieira, N.K.M., Finn, D.S., Simmons, M.P., \& Kondratieff, B.C.

710 (2006). Functional trait niches of North American lotic insects: traits-based ecological

711 applications in light of phylogenetic relationships. Journal of the North American Benthology

712 Society, 25, 730-755.

713 Ponge, J.F., Dubs, F., Gillet, S., Sousa, J.P., \& Lavelle, P. (2006). Decreased biodiversity in

714 soil springtail communities: the importance of dispersal and landuse history in heterogeneous

715 landscapes. Soil Biology \& Biochemistry, 38, 1158-1161.

716 Porter, J.H. (1998). Scientific databases for environmental research. In: W.K.P. Michener,

717 J.H.; Stafford, S.G. (Ed.), Data and information management in the ecological sciences: A

718 resource guide (pp. 41-46). University of New Mexico, Albuquerque, New Mexico, U.S.A.:

719 Long Term Ecological Research Network Office.

720 R Development Core Team. (2010). R: A Language and Environment for Statistical

721 Computing. Vienna, Austria.

722 Relya, R., A. (2001). Morphological and behavioral plasticity of larval anurans in response to

723 different predators. Ecology Letters, 82.

724 Ribera, I., Doledec, S., Downie, I.S., \& Foster, G.N. (2001). Effect of land disturbance and

725 stress on species traits of ground beetle assemblages. Ecology, 82, 1112-1129.

726 Russell, D.J., Vorwald, J., Franzke, A., Höfer, H., Horak, F., Lesch, S., Rick, S., Römbke, J.,

727 Schmelz, R., \& Xylander, W.E.R. (2012). The Edaphobase GBIF project of germany - a new

728 online soil organism data warehouse. 16th International Colloquium on Soil Zoology.

729 Coimbra, Portugal. 
730

731

732

733

734

735

736

737

738

739

740

741

742

743

744

745

746

747

748

749

750

751

752

753

754

755

756

757

758

759

760

761

762

763

764

765

766

767

768

769

770

771

772

Salmon, S., \& Ponge, J.F. (2012). Species traits and habitats in springtail communities: A regional scale study. Pedobiologia, 295- 301.

Schmallfuss, H. (1984). Eco-morphological strategies in terrestrial isopods. Biology (The) of terrestrial isopods. Symposium (1983), 53, 49-63.

Semper, K. (1880). Die Natürlichen Existenzbedingungen der Thiere. Leipzig, Germany: Brockhaus.

Shelford, V.E. (1913). Animal Communities in Temperate America. Chicago Press.

Silva, P.M.d., Aguiar, C.A.S., Faria e Silva, I.d., \& Serrano, A.R.M. (2011). Orchard and riparian habitats enhance ground dwelling beetle diversity in Mediterranean agro-forestry systems. Biodiversity and Conservation, 20, 861-872.

Southwood, T.R.E. (1977). Habitat, the Templet for Ecological Strategies? Journal of Animal Ecology, 46, 336-365.

Statzner, B., Dolédec, S., \& Hugueny, B. (2004). Biological trait composition of European stream invertebrate communities: Assessing the effects of various trait filter types. Ecography, 27, 470-488.

Statzner, B., Hildrew, A.G., \& Resh, V.H. (2001). Species traits and environmental constraints: Entomological research and the history of ecological theory. Annual Review of Entomology (pp. 291-316).

Stearns, S.C. (1992). The Evolution of Life Histories. Oxford: University Press, New York.

Swift, M.J., Heal, O.W., \& Anderson, J.M. (1979). Decomposition in Terrestrial Ecosystems. Blackwell Scientific Publications, Oxford.

Thuiller, W., Lavorel, S., Midgley, G., Lavergne, S.b., \& Rebelo, T. (2004). Relating plant traits and species distributions along bioclimatic gradients for 88 Leucadendron taxa. Ecology, 85, 1688-1699.

Tropek, R., Spitzer, L., \& Konvicka, M. (2008). Two groups of epigeic arthropods differ in colonising of piedmont quarries: the necessity of multi-taxa and life-history traits approaches in the monitoring studies. Community Ecology, 9, 177-184.

Vanbergen, A.J., Woodcock, B.A., Koivula, M., Niemelä, J., Kotze, D.J., Bolger, T., Golden, V., Dubs, F., Boulanger, G., Serrano, J., Lencina, J.L., Serrano, A., Aguiar, C., Grandchamp, A.C., Stofer, S., Szel, G., Ivits, E., Adler, P., Markus, J., \& Watt, A.D. (2010). Trophic level modulates carabid beetle responses to habitat and landscape structure: a pan-European study. Ecological Entomology, 35, 226-235.

Vandewalle, M., de Bello, F., Berg, M.P., Bolger, T., Dolédec, S., Dubs, F., Feld, C.K., Harrington, R., Harrison, P.A., Lavorel, S., da Silva, P.M., Moretti, M., Niemelä, J., Santos, P., Sattler, T., Sousa, J.P., Sykes, M.T., Vanbergen, A.J., \& Woodcock, B.A. (2010). Functional traits as indicators of biodiversity response to land use changes across ecosystems and organisms. Biodiversity and Conservation, 19, 2921-2947.

Verhagen, R., Diggelen, R.v., \& Vermeulen, R. (2008). Community assemblage of the Carabidae fauna in newly created habitats. Baltic Journal of Coleopterology, 8, 135-148.

Villéger, S., Mason, N.W.H., \& Mouillot, D. (2008). New multidimensional functional diversity indices for a multifaceted framework in functional ecology. Ecology, 89, 2290-2301.

Violle, C., Navas, M.L., Vile, D., Kazakou, E., Fortunel, C., Hummel, I., \& Garnier, E. (2007). Let the concept of trait be functional! Oikos, 116, 882-892. 
773 Warnaffe, G.d.B.d., \& Dufrene, M. (2004). To what extent can management variables explain

774 species assemblages? a study of carabid beetles in forests. Ecography, 27, 701-714.

775 Webb, C.T., Hoeting, J.A., Ames, G.M., Pyne, M.I., \& LeRoy Poff, N. (2010). A structured

776 and dynamic framework to advance traits-based theory and prediction in ecology. Ecology

777 Letters, 13, 267-283.

778 Wolters, V. (2001). Biodiversity of soil animals and its function. European Journal of Soil

779 Biology (pp. 221-227).

780 Wright, J.P., Naeem, S., Hector, A., Lehman, C., Reich, P.B., Schmid, B., \& Tilman, D.

781 (2006). Conventional functional classification schemes underestimate the relationship with

782 ecosystem functioning. Ecology Letters, 9, 111-120.

783

784 


\section{Appendix A. Supplementary data}

2

3 The heterogeneity of data informing trait (numeric, textual), the missing data and finally the

4 heterogeneity of individuals within and between taxa led authors to transform trait raw data to

5 (i) allow their comparison and (ii) reduce continuous data into a limited number of subsets.

6 The fuzzy coding is one of the techniques which allowed the synthesis of data informing trait

7 from different formats by their discretization into trait sub-classes called "categories"

8 (Chevenet, Dolédec \& Chessel 1994).

9 In soil invertebrate ecology, the main aim of the fuzzy coding is to discretize data informing a trait for a taxon into categories. Category choice is a priori done and must be though out from sound biological hypotheses and from the accuracy of data informing trait. For instance, the "integument sclerotization" trait could be divided into 2 categories: unsclerotized or sclerotized. The thesaurus described in our review can serve as a stable semantic reference which fixes both trait names but also their category number and names (also category name synonyms).

Once trait categories were defined, the information for a taxon obtained from a literature source must be coded for each trait category by an affinity score. For instance, affinity scores can range from 0 to 3 , from no to very high affinity of the taxon to a trait category. Then, affinity scores of several sources of a trait were converted to a percentage for building a trait profile for the considered taxon.

The way an affinity score is attributed to the categories was generally not clearly explained in the literature review. That is a point we want to fix in this review by proposing detailed protocols depending on the data format informing the trait. 
Trait informed by numerical data

Literature sources commonly proposed one or several values for a trait. We propose to only use the minimum and the maximum values. Then, affinity scores are attributed to each $a$ priori category. For each category, it is done according to "the space of the interval between the maximum and the minimum category values" occupied by "the interval between the maximum and the minimum trait values”. For this, each category interval was divided into three sub-categories:

- $\quad[a ; a+(b-a) * 1 / 3[\quad$ which represents the first $33 \%$ of the category interval - $\quad[a+(b-a) * 1 / 3 ; a+(b-a) * 2 / 3$ [ which represents the middle $33 \%$ of the category interval

- $\quad[a+(b-a) * 2 / 3 ; b$ [ which represents the last $33 \%$ of the category interval where $\mathrm{a}$ and $\mathrm{b}$ are the minimum and the maximum values of the category.

Then if the interval between the maximum and the minimum trait values is included into

- $\quad$ No sub-category, then the affinity will be $\mathbf{0}$.

- One sub-category, then the affinity score will be $\mathbf{1}$.

- Two sub-categories, then the affinity score will be $\mathbf{2}$.

- $\quad$ Three sub-categories, then the affinity score will be 3 .

Then, affinities scores of several sources for a trait were converted to percentages building a trait profile for the considered taxon.

\section{Example:}


We took the maximum and minimum body length of Lumbricus castaneus from different literature sources (Table 1).

Table 1. Examples of minimum and maximum body length values for Lumbricus castaneus from two literature sources

\begin{tabular}{|c|c|c|}
\hline Source & Minimum body length (mm) & Maximum body length (mm) \\
\hline Bouché (1972) & 25 & 60 \\
\hline Sims \& Gerard (1985) & 30 & 45 \\
\hline
\end{tabular}

We proposed to divide the body length trait into 6 categories: [20;35[, [35;50[, [50;100[, [100;150[, [200;400[. Then we attribute the affinity scores by category following the rules above described (Table 2). For instance, the Bouché's interval (25-60) is not included into the first sub-category [20;25[ but is included into the two other sub-categories [25;30[ and [30;35[ of the first category [20;35[. As a consequence, affinity score for the first category for Bouché is 2. The second category [35;50[ is completely filled by the Bouché's interval (25-60). That is why the affinity score is 3 .

Table 2. Affinity scores for Lumbricus castaneus from two literature sources

\begin{tabular}{|c|c|c|c|c|c|}
\hline Source & {$[20 ; 35[$} & {$[35 ; 50[$} & {$[50 ; 100[$} & {$[100 ; 150[$} & {$[200 ; 400[$} \\
\hline Bouché (1972) & 2 & 3 & 1 & 0 & 0 \\
\hline Sims et al. (1985) & 1 & 3 & 0 & 0 & 0 \\
\hline
\end{tabular}

Finally, affinity scores of several sources were converted to percentages to create a trait profile (Table 3). For instance, for the first category, the percentage is calculated as being the ratio between the sum of affinity scores for this category $(2+1)$ and the sum of all the affinity scores (10).

Table 3. Trait profile for Lumbricus castaneus

\begin{tabular}{|c|c|c|c|c|c|}
\hline Taxon & {$[20 ; 35[$} & {$[35 ; 50[$} & {$[50 ; 100[$} & {$[100 ; 150[$} & {$[200 ; 400[$} \\
\hline Lumbricus castaneus & 0.3 & 0.6 & 0.1 & 0 & 0 \\
\hline
\end{tabular}

\section{Trait informed by textual data}

The text informing a trait generally contains two kinds of information: (i) some words which correspond to category names or their synonyms and (ii) adjectives which qualify categories. 
For instance, the diet description for Amara aenea from (Brandmayr 1972) "Italy, in the field: mostly seeds" contains the word "seed" which corresponds to a category of the "diet” trait and "mostly", an adverb. An affinity score must be attributed to each a priori category. We propose to do this according to (i) the number of categories embodied in a given literature source and (ii) the strength of adverbs characterizing each category. To do this, we first build a correspondence table (Table 4) between the frequently found adverbs in the literature and their strength.

Table 4. Correspondence table between adjectives and their strength

\begin{tabular}{|c|c|c|}
\hline Strong & Medium & Weak \\
\hline absolutely & almost & absent \\
\hline almost entirely & common(ly) & accidentally \\
\hline almost exclusively & frequently & episodically \\
\hline always & generally & exceptionally \\
\hline constantly & moderately & few \\
\hline continually & moderately & infrequently \\
\hline decidedly & more (in, during) & less frequently \\
\hline definitely & mostly & maybe \\
\hline entirely & often frequent & mentioned \\
\hline especially & particularly numerous & missing \\
\hline essentially & preferably & more or less \\
\hline exceptionally & quite often & never \\
\hline fully & regularly & occasionally \\
\hline mainly & to like & optionally \\
\hline majority & to prefer & partially \\
\hline maximum & to require & possibly \\
\hline numerically dominant in & usually & presumed to be \\
\hline overwhelmingly & well known & probably \\
\hline particularly & & rarely \\
\hline persistently & & scarcely \\
\hline predilection for & & slightly \\
\hline predominantly & & sometimes \\
\hline purely & & sometimes \\
\hline significantly & & somewhat \\
\hline specialist & & sporadically \\
\hline specially & & to seem to \\
\hline specifically & & to tolerate \\
\hline strictly & & transiently \\
\hline strong & & only \\
\hline \multicolumn{3}{|l|}{ strongly favoured } \\
\hline strongly influenced by & & \\
\hline
\end{tabular}




$$
\begin{gathered}
\text { surely } \\
\text { systematically } \\
\text { to avoid } \\
\text { typical }
\end{gathered}
$$

80

\begin{tabular}{|c|c|}
\hline Source & Diet description \\
\hline Davies (1953) & $\begin{array}{c}\text { England, in the field: food of adults: collembola, spiders and } \\
\text { pollen }\end{array}$ \\
\hline $\begin{array}{c}\text { Ribera, Doledec, Downie \& Foster } \\
\text { (2001) }\end{array}$ & Mostly collembola \\
\hline
\end{tabular}

Then, we develop rules to determine affinity scores:

- If there is no adverb:

0 and words of a given literature source correspond to more $(>)$ than 2 $\underline{\text { categories, }}$, then the category will receive an affinity score of $\mathbf{2}$

0 and words of a given literature source corresponds to 1 or 2 categories, then the category will receive an affinity score of $\mathbf{3}$

- If there are adverbs whose:

o strength is “weak”, then the category will receive an affinity score of $\mathbf{1}$

o strength is “medium”, then the category will receive an affinity score of $\mathbf{3}$

o strength is "strong”

- $\quad$ and words of a given literature source correspond to more $(>)$ than 2 $\underline{\text { categories, }}$, then the category will receive an affinity score of $\mathbf{3}$

- and words of a given literature source correspond to 1 or 2 categories, then the category will receive an affinity score of $\mathbf{4}$

Example:

The diet of Loricera pilicornis is described in different literature sources (Table 5). Table 5. Examples of diet description for Amara aenea from two literature sources

99 
We proposed to divide the diet trait into 5 categories: detritivore, microbivore-

microphytophagous, phytophagous, geophagous, zoophagous. Then we attribute the affinity scores by category following the rules above described (Table 6). In the first source, the sentence contains the words corresponding to 2 categories: “collembolan” and "spiders" for the zoophagous category and "pollen” for the phytophagous category. As there are no adverb, affinity scores are 3 for both categories. In the second source, the sentence contains a word "collembola" corresponding to the zoophagous category. A "strong” adjective is present. The affinity score is therefore 4 .

Table 6. Affinity scores for Loricera pilicornis from two literature sources

\begin{tabular}{|c|c|c|c|c|c|}
\hline Source & Detritivore & Microbivore & Phytophagous & Geophagous & Zoophagous \\
\hline Davies (1953) & 0 & 0 & 3 & 0 & 3 \\
\hline Ribera et al. (2001) & 0 & 0 & 0 & 0 & 4 \\
\hline
\end{tabular}

Finally, affinity scores of several sources were converted to percentages to create a trait profile (Table 7). For instance, for the zoophagous category, the percentage is calculated as the ratio between the sum of affinity scores for this category $(3+4)$ and the sum of all the affinity scores (10).

Table 7. Trait profile for Lumbricus castaneus

\begin{tabular}{|c|c|c|c|c|c|}
\hline Taxon & Detritivore & Microbivore & Phytophagous & Geophagous & Zoophagous \\
\hline Loricera pilicornis & 0 & 0 & 0.3 & 0 & 0.7 \\
\hline
\end{tabular}

\section{References for the Appendix}

Bouché, M.B. (1972). Lombriciens de France. Ecologie et Systématique. Brandmayr, P. (1972). Studio ecologico sui Coleotteri Carabid di due formzioni vegetali dell'Istria Montana. Boll. Zool., 39.

Chevenet, F., Dolédec, S., \& Chessel, D. (1994). A fuzzy coding approach for the analysis of long-term ecological data. Freshwater Biology, 31, 295-309. Davies, M.J. (1953). The contents of the crops of some British Carabid Beetles. Ent. mon. Mag., 95. Ribera, I., Doledec, S., Downie, I.S., \& Foster, G.N. (2001). Effect of land disturbance and stress on species traits of ground beetle assemblages. Ecology, 82, 1112-1129. 
127 Sims, R.W., \& Gerard, B.M. (1985). Earthworms. Keys and notes for the identification and study of the 128 species. (Doris M. Kermack and R.S.K. Barnes ed.). London-Leiden-Köln-København: E.J. Brill 129 Dr. W. Backhuys. 